\title{
BATIK MADURA: Menilik Ciri Khas dan Makna Filosofinya
}

\author{
R.A Sekartaji Suminto*)
}

\begin{abstract}
Batik is the cultural heritage of the archipelago that is priceless. Each area in Indonesia has batik tradition, especially in Java and surrounding areas. Batik has been known since centuries ago. Batik type is classified into two major parts, namely inland and coastal batik. Batik Madura is one type of coastal batik has its own beauty, but still not so well known by the public at large. Every region in Madura has a typical batik yield of each, which can be seen from the patterns, motifs and colors. Batik Bangkalan, especially batik gentongan, Tanjung Bumi, it had its own characteristics, namely of how to make it. Gentongan batik dyeing technique requires a special way, which is by doing the barrel stone in a period of 1 month to 1 year. This is the way to produce batik with excellent quality. Gentongan batik color will not fade, even the longer will be more beautiful. Batik Madura is still less popular than Batik Pekalongan, Cirebon or Lasem, but the beauty of Madura batik, especially batik gentongan Tanjung Bumi remained in line with the progress of time, even becoming increasingly popular over time.
\end{abstract}

Keywords: Batik Madura, characteristic, gentongan, Tanjung Bumi

\section{ABSTRAK}

Batik adalah warisan budaya Nusantara yang tak ternilai harganya. Setiap daerah di Indonesia memilik tradisi membatik, khususnya di Pulau Jawa dan sekitarnya. Batik sudah dikenal sejak berabad-abad yang lalu. Jenis batik digolongkan menjadi dua bagian besar, yaitu batik pedalaman dan batik pesisir. Batik Madura adalah salah satu jenis batik pesisir yang memiliki keindahan tersendiri, namun masih belum begitu dikenal oleh masyarakat secara luas. Setiap wilayah di Madura yang menghasilkan batik memiliki ciri khas masing-masing, yang bisa dilihat dari corak, motif dan warnanya. Batik Bangkalan, khususnya batik gentonganTanjung Bumi, memilik ciri khas tersendiri, yaitu dari cara pembuatannya. Teknik pewarnaan batik gentongan memerlukan cara khusus, yaitu dengan melakukan perendaman dalam gentong batu dalam jangka waktu 1 bulan hingga 1 tahun. Hal ini untuk menghasilkan batik dengan kualitas prima. Warna batik gentongan tidak akan memudar, bahkan makin lama akan makin indah. Batik Madura memang masih kurang populer dibandingkan dengan batik Pekalongan, Cirebon atau Lasem, namun keindahan batik Madura, terutama batik gentongan Tanjung Bumi tetap bertahan seiring dengan kemajuan jaman, bahkan menjadi semakin terkenal dari waktu ke waktu.

Kata kunci : Batik Madura, ciri khas, gentongan, Tanjung Bumi

\footnotetext{
* Sekartaji Suminto (sekartaji@yahoo.com), Mahasiswa Program Penciptaan dan Pengkajian Seni Pascasarjana Institut Seni Indonesia Yogyakarta
} 


\section{PENDAHULUAN}

Batik merupakan bentuk kerajinan yang memiliki nilai seni tinggi dan telah menjadi bagian dari budaya Indonesia sejak lama.

Batik itu sendiri sebenarnya memang sudah menjadi pakaian tradisional yang menasional hampir disetiap acara besar bahkan di hari hari tertentu, wajib mengenakan batik.

Di Indonesia banyak sekali motif dan corak serta warna batik yang tentunya memiliki kesan filosofis dan penggambaran keseharian di mana asal batik tersebut.

(Asti Musman dan Ambar B. Arini, Batik: Warisan Adiluhung Nusantara, hal. 2-4, 2011).

Helen Ishwara dalam bukunya Benang Raja: Menyimpul Keelokan Batik Pesisir, menyebutkan bahwa metode membatik sebenarnya sudah dikenal sejak beribu-ribu tahun, dengan tata cara yang berbeda sesuai dengan jamannya. Inti dari membatik sebenarnya adalah membuat ragam hias pada kain dengan metode merintang warna. Caranya adalah menggambari kain dengan zat yang tidak tembus cairan pencelup warna. Setelah proses pencelupan selesai, zat perintang warnanya dirontokkan, sehingga tampaklah motif yang terlindung dari balik zat perintang warna tersebut.

Di pelbagai bagian Nusantara, metode ini juga sudah berabad-abad dikenal. Namun metode menggunakan zat lilin yang disebut dengan nama malam sebagai bahan perintang warna yang dibubuhkan dengan canting, menurut Robyn Maxwell dalam bukunya Textille of Southern Asia: Tradition, Trade and Transformation, batik mungkin baru berkembang pada awal abad XVII di pedalaman Jawa tengah. Sebelum canting dikenal, perintang warna dibubuhkan pada alat lain, misalnya tangkai bambu. Zat perintang warna pun juga beragam, diantaranya adalah bubur ketan.

Secara garis besar, batik digolongkan menjadi dua bagian pokok, yaitu batik pedalaman dan batik pesisiran. Batik pedalaman adalah batik-batik yang dihasilkan dari daerah yang jauh dari laut. Misalnya Surakarta, Yogyakarta, Indramayu, Semarangan dan sebagainya. Warna-warna batik pedalaman pada umumnya adalah warna-warna tanah seperti warna coklat, biru tua, putih kecoklatan atau putih kebiruan. Batik pesisir adalah batik yang dihasilkan oleh daerah-daerah yang dekat dengan pantai, misalnya Pekalongan, Cirebon, Lasem, Tuban dan Madura. Warna-warna batik pesisir biasanya lebih cerah dan lebih kaya warna, seperti warna hijau, kuning, merah terang, biru terang bahkan juga warna oranye dan merah muda atau pink.

Meskipun kata batik berasal dari bahasa Jawa, kehadiran batik tidak tercatat dengan pasti. Menurut G.P Rouffaer, teknik batik kemungkinan diperkenalkan dari India atau Sri Langka pada abad ke 6 atau ke 7 oleh para pedagang yang mendarat di sekitar pesisir Indonesia, diantaranya adalah Madura (S.K Sewan Susanto, S.Tek., Seni Kerajinan Batik Indonesia, hal 10, 2008)

\section{PEMBAHASAN}

\section{Sejarah Singkat Batik Madura}

Mengenal sejarah batik berarti mencintai karya seni anak bangsa. Dalam berbagai literatur disebutkan bahwa sejarah batik Madura tidak terlepas dari keberadaan kerajaan di Pamelingan yang sekarang lebih dikenal dengan nama Pamekasan. Keraton Mandilaras yang 
merupakan pusat pemerintahan di bawah pimpinan Pangeran Ronggosukowati merupakan cikal bakal berdirinya kabupaten Pamekasan Madura.

Batik tulis Madura mulai dikenal masyarakat luas antara abad ke 16 17. Diawali ketika terjadi peperangan di Pamekasan Madura antara Raden Azhar (Kiai Penghulu Bagandan) melawan Ke' Lesap. Raden Azhar merupakan ulama penasihat spriritual Adipati Pamekasan yang bernama Raden Ismail (Adipati Arya Adikara IV). Sedangkan Ke' Lesap merupakan putera Madura keturunan Cakraningrat I.

Dalam perjalanannya, sejarah batik madura banyak dipengaruhi motif batik Yogyakarta dan Solo. Adanya kesamaan motif kain batik Madura dan Jogjakarta karena ada hubungan darah antara raja Mataram dengan para pembesar di Madura. Kerajaan Bangkalan pada zaman raja Cakraningrat I adalah bawahan Kesultanan Mataram yang dipimpin Sultan Agung. Dalam berkembangannya, batik Madura memiliki ciri khas dan karakter yang berbeda dengan batik di Jawa pada umumnya.

Tokoh penting yang dianggap paling berjasa dalam mengenalkan batik ke Madura adalah Adipati Sumenep, Arya Wiraraja. Tokoh ini sangat dikenal karena memiliki kedekatan dengan Raden Wijaya, pendiri kerajaan Majapahit

Dalam beberapa referensi disebutkan bahwa batik parang merupakan kain batik dengan tampilan gambar garis melintang simetris. Ketika memakai kain batik motif parang, Raden Azhar memiliki kharisma, tanpak gagah berwibawa. Sejak itulah, batik menjadi perbincangan di kalangan masyarakat Madura, terutama pembesar-pembesar di Pamekasan. Sejak itulah perbincangan mengenai kain batik menjadi daya tarik masyarakat untuk mengetahuinya

$$
\text { Batik Yogyakarta memiliki }
$$
kecenderungan warna lembut, kalem sesuai dengan karakter masyarakat setempat. Demikian halnya dengan motif batik Solo. Lain halnya dengan motif batik Madura yang memiliki kekhasan dalam hal warna yang kuat, cerah, dan berani. Hal inilah yang membuat batik Madura terlihat beda dengan batik pada umumnya.

Kini, batik Madura mulai menemukan kejayaannya. Hal ini berawal dari dengan diakuinya batik sebagai warisan budaya dari Indonesia dan dengan berdirinya jembatan Suramadu yang menghubungkan pulau Jawa dan Madura semakin mempermudah akses kunjungan ke pulau Madura, sehingga batik madura makin dikenal oleh para wisatawan. Banyak sentra batik di Madura, seperti sentra batik tulis madura Tanjung Bumi di Bangkalan, sentra batik tulis Madura Banyumas Klampar, Pamekasan, dan sentra batik tulis Madura Pakandangan Sumenep. Dan kini, Pemkab Pamekasan menetapkan desa Banyumas Klampar kecamatan Proppo sebagai desa batik Madura. Tak hanya itu, sebuah pasar batik terbesar di dunia (dilihat dari jumlah pedagang batik) juga telah dibuka di sana.

\section{Ciri khas dan Jenis Motif Batik Madura}

Batik Madura memiliki ciri khas tersendiri yang berbeda dengan batik dari daerah lain, seperti batik Yogyakarta, batik solo, batik Pekalongan dan batik Cirebon. Batik Madura memiliki ciri dengan motif batik yang menggunakan warna cerah dan 
berani, seperti warna merah, kuning dan hijau. Selain itu, motif batik Madura banyak menggunakan motif bunga dan daun. Banyak juga motif batik madura memiliki kesamaan dengan motif batik Yogyakarta, karena ada hubungan darah antara raja mataram dengan para pembesar di Madura pada dahulu kala. Batik Madura juga dikenal dengan motif yang lebih bebas.

Pulau Madura dikenal sebagai pulau penghasil garam, mungkin itulah salah satu sebab mengapa batik Madura banyak bercorak dengan titik-titik berwarna putih, layaknya butiran garam yang dihasilkan di pulau Madura. Titik putih ini menjadi salah satu ciri utama dari batik Madura. Secara umum desain batik Madura terpengaruh oleh kepantaian pulau Madura. Warna merah, hijau, biru dan kuning menjadi simbol bagaimana batik madura menyesuaikan corak alam asli pulau Madura.

Motif batik Madura memiliki ciri khas tersendiri yang tidak dimiliki oleh batik dari daerah lain. Ciri khas batik madura yang sangat mudah dikenali adalah adanya warna merah pada motif bunga, tangkai atau daun.

Secara garis besar, karakteristik batik Madura dapat dilihat dari dua hal, yaitu warna dan motifnya. Dari segi warna, karakteristik warna batik Madura cenderung berani dan tegas, seperti warna merah, kuning, biruh (hijau, dalam bahasa Indonesia) dan warna biru itu sendiri.

Warna yang digunakan memberi kesan cerah serta menonjol dan beragam seperti merah, kuning, hijau dan biru. Masing-masing warna memiliki arti tersendiri yaitu: Merah, melambangkan karakter masyarakat Madura yang kuat dan keras; Hijau, melambangkan warna religi di mana beberapa kerajaan Islam didirikan dan berkembang di Madura; Kuning, melambangkan bulir-bulir padi pertanian penduduknya; Biru, melambangkan warna laut yang mengelilingi sekitar pulau Madura.

Warna-warna tersebut dihasilkan dari pewarna alam (soga alam) seperti mengkudu dan tingi untuk menghaislkan warna merah, daun tarum untuk warna biru, kulit mengkudu yang dicampur dengan tawas akan memberika efek warna hijau (biruh). Efek terang gelap pada batik Madura dihasilkan melalui perendaman kain yang telah diproses. Lama perendaman berkisar antara 1 bulan sampai 1 tahun. Perendaman ini juga akan membuat warna batik menjadi lebih awet dari biasanya. Seiring dengan perkembangan jaman, warna-warna tersebut mengalami banyak perubahan makna dan jenisnya pun semakin berkembang dengan adanya warna ungu, oranye, bahkan juga pink (merah muda), namun demikian batik gentongan tetap bertahan pada warna alam klasik.

Motif batik merupakan bagian kritikal dari proses pembuatan batik itu sendiri, karena goresan canting dan gerak tangan pembatik juga melibatkan pikiran dan perasaannya. Beberapa motif batik Madura yang terkenal diantaranya adalah Sekarjagat, Daun Memba (daun Mojo), Gorek Basi, Keraben Sapeh, Kempeng Saladerih, Padih Kepa', Tasik Melaya, Kembang Randu, Ola-Ola, Panji Susi dan sebagainya.

Ciri khas lainnya yang dimiliki oleh batik Madura adalah banyaknya tarikan garis pada satu desain batik.

Di Madura, membatik merupakan budaya yang diwariskan turun-temurun. Corak dan ragamnya begitu bebas dan unik. Satu helai kain batiknya dibuat dengan keterampilan individu secara satuan kain. 
Bahkan saat ini pun mereka masih mempertahankan cara tradisional pembuatannya dengan ditulis menggunakan bahan pewarna alami yang ramah lingkungan.

Berikut ini adalah ciri khas batik Madura berdasarkan asal daerahnya:

1. Pamekasan: batik Pamekasan lebih berani dengan mengunakan warna-warna yang tajam dan cerah seperti Sekarjagat, Keong Mas, Matahari, Daun Memba (daun mojo), dan Gorek Basi dan desainnya pun sangat beragam. Pada batik Pamekasan, biasanya juga diisi dengan 'serat kayu' atau istilahnya mo' ramo'(akar-akaran) pada bagian yang kosong. Beberapa motif batik Pamekasan sudah didaftarkan seperti: Keraben Sapeh, Sakereh, Kempeng Saladerih, Padih-kepa, dan Manik-manik.

2. Bangkalan: Lokasi tepatnya di Tanjungbumi, batiknya dibuat dengan menggunakan teknik khusus yang biasa dikenal batik gentongan. Batik Bangkalan coraknya beragam dan berwarna cerah karena termasuk kategori batik pesisiran. Motif batik Bangkalan lebih dari seribu jenis. Nama motifnya terkait gambar apa dan cara pewarna yang dikonsonankan dengan bahasa daerah setempat. Namanama motif tersebut diantaranya adalah: ramo, banjar ramo, rongterong, perkaper, rawan, serat kayu, panca warna, dan sebagainya. Batik gentongan merupakan batik khas Tanjungbumi. Cirinya memiliki warna yang sangat cerah, beragam, dan pengerjaannya yang halus. Kebanyakan mempunyai motif sik melaya, kembang randu, ola-ola, burung hong, panji susi, dan lain sebagainya.

3. Sampang: Batik dari sampang biasa dikenal dengan nama Batik Kotah, memiliki motif khas Madura berupa flora dan fauna (misalnya : motif kembang dan burung) dengan warna paling dominan yaitu merah dan hijau di atas bahan sutera dan katun yang tidak kalah dengan batik daerah lain.

4. Sumenep : batik dengan corak satu warna saja meskipun tetap bernuansa cerah. Batik Madura terkenal dengan warna dan motif naturalis. Warna utamanya adalah merah, merah tua atau jingga, biru tua, hijau tua, hitam dan putih. Pengerjaan batik Madura tidak sehalus batik Jawa, tata warnanya sangat menyolok, begitu juga motifnya, yang juga besar, tegas. Hal ini sejalan dengan alam Madura yang keras dan watak orang Madura yang berani dan tegas.

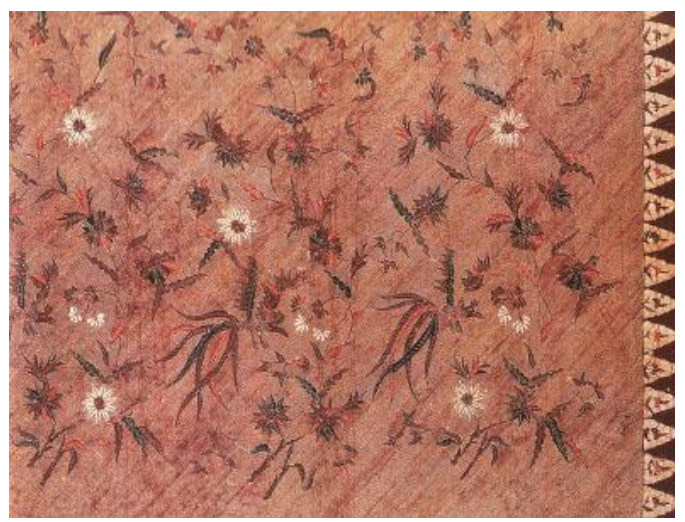

Gambar 1. Batik Bangkalan Madura dengan motif bunga (Sumber : http//artscraftindonesia.com)

Batik Madura memiliki elemen motif seperti isen yang disebut guri yang berarti coret-coretan. Guri digunakan sebagai latar atau digunakan sebagai isen. Guri biasanya berbentuk bendabenda yang akrab dalam kehidupan seharihari dan berbagai jenis tumbuh-tumbuhan. Guri merupakan ciri khas batik Madura. Jumlah jenis dan halusnya pengerjaan guri memegang peranan dalam menentukan mutu sehelai batik. Batik 
Madura biasanya diberi nama berdasarkan jenis gurinya, atau kadang-kadang juga berdasarkan khayalan pembatik semata. Apabila sehelai kain memiliki beberapa jenis guri, maka kain itu akan dinamai sesuai jenis guri yang paling menonjol. Beberapa guri seperti motif sekar jagad, sibasi, topa' saseba.

Orang Madura dikenal sebagai pelaut yang tangguh. Madura sejak dahulu mempunyai hubungan dagang dengan Jambi, Cirebon, Pekalongan, Lasem dan beberapa tempat lain di Indonesia. Hal ini mempengaruhi seni batiknya. Misalnya motif fajar menyingsing serupa dengan merak ngibing dari Indramayu dan Garut. Batik Madura juga mendapat pengaruh tata warna dari Lasem, walaupun tata warna Madura lebih kuat dan berani. Seperti batik daerah lain, pengaruh SoloYogya juga terdapat pada batik Madura, seperti pada sabet rantay, sabet kraton dan pisang Bali.

Batik Madura juga tak lepas dari pengaruh kebudayaan Cina yang terlihat pada motif burung hong, kupu-kupu, banji dan lain-lain. Pengaruh India juga terlihat pada ragam hias kemeh yang berarti keong. Terdapat pula kain batik dengan nama motif blendeh yang berarti Belanda, karena ragam hiasnya berdasarkan karangan bunga bergaya Belanda.

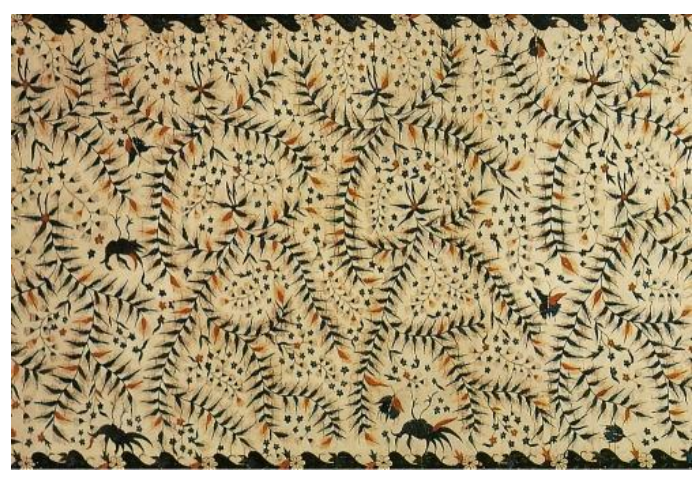

Gambar 2. Batik Sumenep (Sumber : koleksi kedutaan besar Amerika di Jakarta, foto : Sekar, 2014)

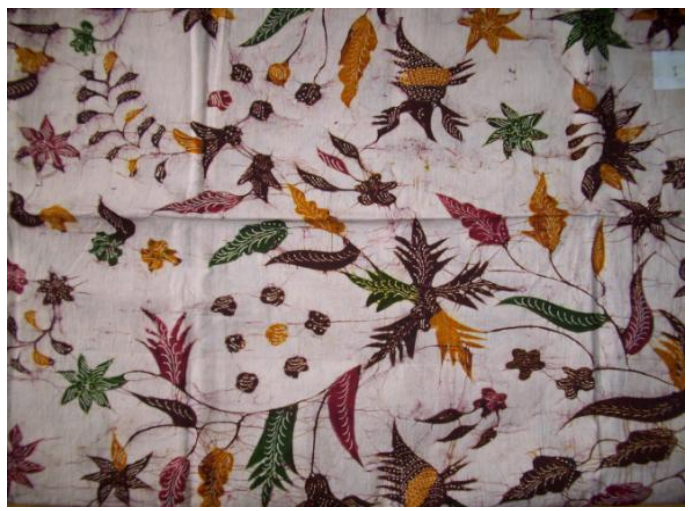

Gambar 3. Batik Gentongan Tanjung Bumi Madura motif bunga Tar Potehan (latar putih) (Sumber :

koleksi pribadi, foto : Sekar-2014)

\section{Pengaruh Asing Pada Batik Madura}

Motif-motif batik Madura juga mengalami pengaruh corak dari negara lain. a. Motif Pusung atau Pucuk rebung.

Hal ini dapat dilihat, misalnya dari bentuk kepala kain batik Madura yang umumnya bercorak pusung atau biasa juga disebut pucuk rebung, yaitu ragam hias berupa deretan segitiga sama kaki. Pusung menunjukkan pengaruh kain patola dan kain sembagi dari Pantai Koromandel, India.

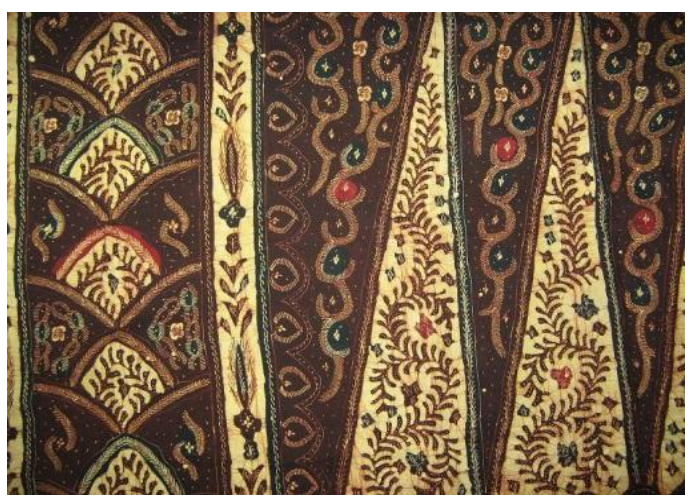

Gambar 4. Motif Pusung atau Pucuk Rebung pada batik Tanjung Bumi Madura (Sumber : http://www.tikbatikmadura.com) 


\section{b. Motif Buketan}

Motif lain yang mendapat pengaruh asing adalah motif buketan yang sering terdapat pada badan kain sarung batik Madura. Menurut Helen Ishwara dalam bukunya yang berjudul Benang Raja: Menyimpul Keindahan Batik Pesisir, motif buketan adalah ragam hias yang berupa rangakaian bunga atau buket (bouquet). Motif ini menunjukkan adanya pengaruh Eropa. Perkembangan motif buketan sejak tahun 1900an sampai 1960an hingga saat sekarang masih banyak disukai oleh khalayak.

Pada era tahun 1910an, badan sarung batik Madura bermotif buketan kebanyakan berlatar warna krem, sebab pada masa itu masih banyak wanita keturunan Belanda, bahkan juga wanitawanita Belanda totok yang menyukai warna lembut. Meskipun begitu, buketan dengan warna-warna cerah seperti merah, biru dan hijau juga sudah ada dan disukai oleh orangorang lokal (penduduk asli Madura). Sekitar tahun 1930an, wanita Belanda yang memakai sarung berkurang. Selera kaum wanita keturunan Cina yang umumnya menyukai warna yang cerah, mempengaruhi warna batik masa itu. Selain warna yang berubah, motif tanaman digantikan dengan motif bunga potong yang disusun dalam bentuk buket.

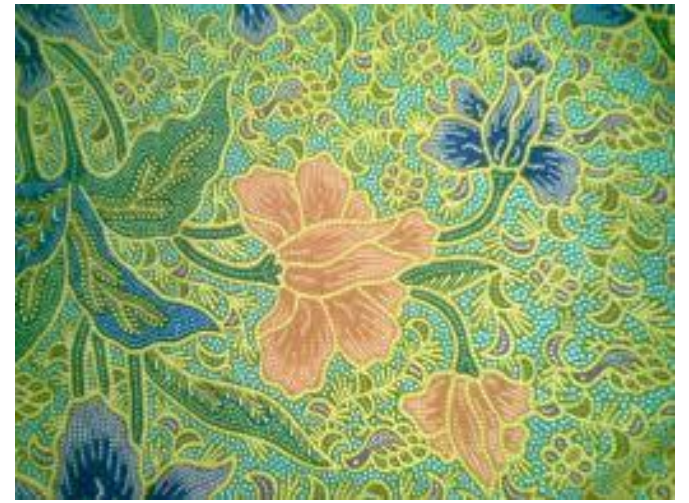

Gambar 4. Motif buketan pada batik Tanjung Bumi Madura (Sumber : ochaneysa-rumahbatikindonesia. blogspot.com)

\section{c. Motif Burung Hong}

Motif burung hong merupakan motif yang ditemukan sepanjang zaman dalam perbatikan. Burung hong (fenghuang) sering salah kaprah disamakan dengan burung phoenix. Burung phoenix sebenarnya adalah burung merak jantan yang menjelma menjadi burung api. Burung ini selalu digambarkan berwarna merah menyala dan tidak pernah memiliki pasangan. Sedangkan burung hong dianggap sebagai ratu segala burung, yang memiliki warna sangat cantik dan mempunyai pasangan.

Makhluk rekaan ini sudah dikenal sejak lebih dari 8.000 tahun yang lalu di Cina. Burung hong ditampilkan dalam berbagai gaya, tidak ada patokan baku perihal penampilannya. Pada awalnya burung hong selalu ditampilkan berpasangan, yaitu feng (burung jantan) dan huang (burung betina). Feng memiliki 5 bulu ekor yang panjang dan melengkung ujungnya (angka ganjil adalah lambang dari yang-sifat laki-laki), sedangkan huang memiliki dua (2) bulu ekor (angka genap melambangkan yin-sifat wanita). Namun demikian kemudian fenghuang digambarkan sebagai seekor burung saja. 
Bulu ekornya berwarna hitam, putih, merah, hijau dan kuning, yang melambangkan kemurahan hati, kemanusiaan, kejujuran dan ketelitian, tenggang rasa, pengetahuan, kesetiaan dan integritas. Namun dalam perkembangan seni batik pesisir, khususnya batik Madura, warna bulu ekor ini bisa menjadi warna apa saja.
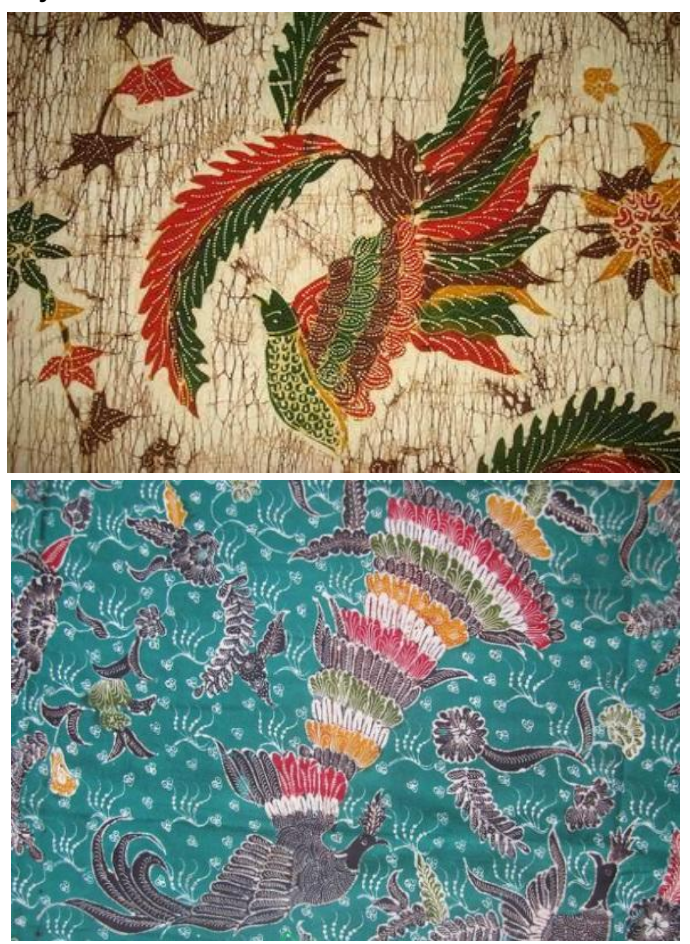

Gambar 5. Motif burung hong batik Bangkalan, Madura (Sumber : koleksi pribadi, foto : Sekartaji, 2014)

\section{d. Motif Bunga Seruni}

Motif bunga seruni sering muncul dalam batik pesisiran. Motif ini mendapat pengaruh dari Cina dan Jepang. Di Cina, seruni adalah salah satu dari empat tanaman yang dimuliakan. Tiga yang lainnya adalah bambu, plum dan anggrek. Sedangkan di Jepang bunga seruni digunakan sebagai tanda meterei (stempel) kaisar Jepang, bahkan tahka kerajaan Jepang pun di sebut sebagai Tahta Seruni.

Dalam bahasa Madura motif bunga disebut bang, yang artinya kembang (bunga). Motif bang atau bunga yang cukup umum dalam batik Madura diantaranya adalah kembang randu, motif bang ompai, bang biron dan bang ni'runi.

Selain motif-motif di atas, masih ada beberapa motif lain yang mendapatkan pengaruh dari luar. Diantaranya adalah motif blendeh, yang mendapat pengaruh dari motif-motif Delf, Belanda yang mempunyai warna khas, yaitu biru dan putih.

\section{Batik Gentongan Tanjung Bumi, Bangkalan, Madura}

Gentongan merupakan batik khas Tanjung Bumi. Cirinya memiliki warna yang sangat cerah, beragam, dan pengerjaannya yang halus. Kebanyakan mempunyai motif sik melaya, kembang randu, ola-ola, burung hong, panji susi, dan lain sebagainya. Batik gentongan dikerjakan paling cepat 1 tahun. Prosesnya direndam dalam gentong selama 6 bulan kemudian setelah digambar, batik belum jadi itu direndam lagi selama 3 sampai 4 bulan. Harga selembar kain batik gentongan yang halus bisa mencapai hingga 3,5 juta rupiah. Harga tersebut tergantung dari tingkat kesulitan desain dan lamanya proses pembuatan. Saat ini batik gentongan termasuk yang paling banyak diminati para kolektor.

Batik gentongan hanya diproduksi di Tanjung Bumi, Bangkalan, Madura. Salah satu desa yang membuat batik gentongan ini adalag desa Paseseh yang terletak di Kecamatan Tanjung Bumi, Kabupaten Bangkalan, Madura. Secara geografis desa Paseseh terletak di pantai utara Madura yang tanahnya kurang subur, sebab mengandung kapur dalam kadar yang cukup tinggi dan juga berpasir.

Selain desa Paseseh, masih ada 2 desa lainnya yang juga menghasilkan batik 
gentongan, yaitu desa Tanjungbumi dan desa Bandangdaja.

Menurut Adi Kusrianto dalam buku

Batik: Filosofi, Motif \& Kegunaan, masyarakat Tanjung Bumi sekitar 200 tahun yang lalu (awal abad ke 19) sedang melakukan perjalanan pulang dari berdagang ternak di Kalimantan yang kemudian terserang badai sehingga terdampar di Pekalongan. Mereka kemudian membeli kain batik sekaligus peralatan dan bahan-bahan pewarna. Oleh orang-orang Madura, bahan pewarna kimia ini disebut sebagai kudhu eropah (yang artinya adalah mengkudu a la Eropa).

Kemahiran membatik masyarakat Paseseh sendiri telah ada sejak abad ke 17 dengan teknik pewarnaan yang menggunakan pewarna nabati yang dicelupkan ke dalam gentong khusus yang terbuat dari batu. Dari proses itulah nama batik gentongan didapat.

Batik khas Madura memiliki makna filosofi yang luar biasa disamping pembuatannya yang cukup sulit dan unik, Batik Tanjung Bumi seperti menggambarkan kehidupan keberanian masyarakat Madura.

Karakteristik lain dari batik khas Madura yang terkenal dengan sebutan batik Tanjung Bumi ini adalah seni corak dan motifnya yang menggambarkan aktifitas nelayan serta hewan hewan yang ditemui saat melaut, memang sebagian warga Tanjung Bumi adalah seorang nelayan yang handal.

Seni batik tulis yang menjadi batik khas Madura ini biasanya di kerjakan oleh para perempuan istri seorang nelayan yang disetiap goresannya memaknakan kesetiaan sang istri terhadap suaminya.

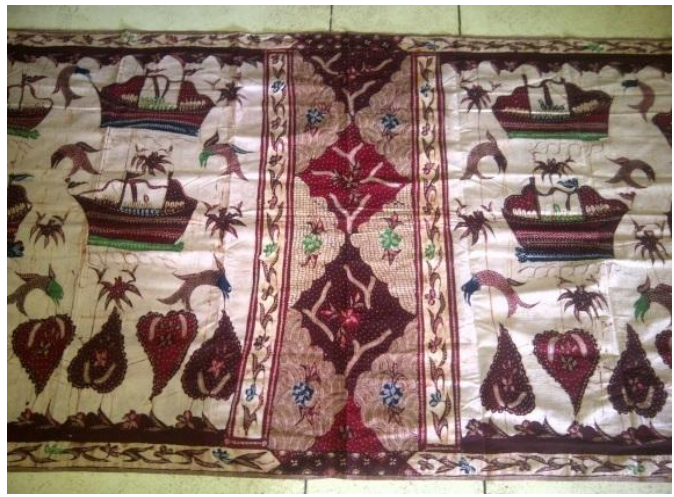

Gambar 6. Batik Tanjung Bumi motif Tasek Melaya (Sumber : koleksi pribadi, foto : Sekartaji, 2014)

Salah satu jenis batik Tanjung Bumi Madura dibuat dengan teknik khusus yaitu batik gentongan.

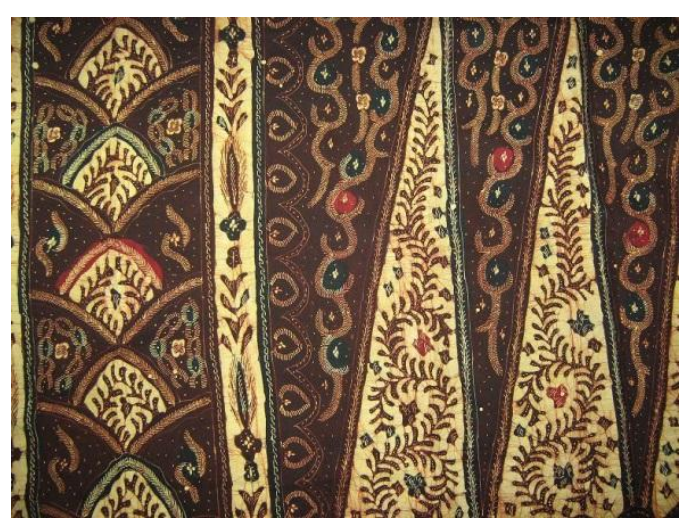

Gambar 7. Batik Gentongan Tanjung Bumi Madura (Sumber : Helen Ishwara, Batik Pesisir:An Indonesian Heritage, hal. 209)

Batik khas Madura ini seakan memiliki makna filosofi yang luar biasa di samping pembuatan nya yang lumayan susah dan unik, Batik Tanjung Bumi seperti menggambarkan kehidupan keberanian masyarakat Madura.

Goresan-goresan tersebut seperti menyimpan kerinduan seorang istri saat di tinggal suaminya melakukan aktifitas pekerjaannya menjadi nelayan, maka tak heran seni batik khas Madura ini dikerjakan secara turun temurun oleh masyarakat Tanjung Bumi dan dikerjakan saat senggang 
sambil menanti sang suami pulang kerja. Proses pembuatan batik Tanjung Bumi memakan waktu yang cukup lama dan sudah barang tentu memiliki harga yang mahal karena di dalam nya terkandung doa untuk keselamatan sang suami dalam bekerja mencari ikan di laut lepas.

Motif lain yang terkenal dari batik gentongan adalah motif Tong Centong. Motif ini diciptakan pada tahun 1950an. Tong Centong berarti alat penyendok nasi. Batik dengan motif ini biasanya dijadikan pemberian mempelai pria kepada mempelai wanita yang dimaknai sebagai simbol jaminan kehidupan untuk istri dan keluarga saat mereka nanti menjalani kehidupan rumah tangga.

Di jaman dahulu, proses batik gentongan ini menghabiskan waktu berbulan-bulan bahkan bisa mencapai 1 tahun hanya untuk sepotong batik gentongan. Motifnya sangat rumit dan detil. Untuk mendapatkan satu warna saja memerlukan perendaman minimal 6 minggu di dalam gentong khusus. Saat ini proses pembuatan batik gentongan masih dipertahankan masyarakat Tanjung Bumi.

Awalnya para istri penduduk Tanjung Bumi membuat batik untuk mengisi waktu luang sambil menunggu suami mereka pulang melaut. $\mathrm{Di}$ desa Tanjungbumi setidaknya ada sekitar 900 perajin batik. Remaja di desa ini mahir membuat batik.

Proses batik gentongan sarat dengan mitos. Sebelum melakukan perendaman dalam gentong batu, masyarakat setempat harus mengadakan semacam ritual kecil, diantaranya adalah berpuasa supaya proses pewarnaan berhasil dengan sempurna. Jika ada warga setempat yang meninggal, maka proses pewarnaan harus dihentikan selama satu minggu.

Dari keseluruhan proses pembuatan batik gentongan, pewarnaan menggunakan gentong batu ini adalah proses yang paling penting dan paling sulit. Diperlukan ketekunan, ketelitian serta keahlian khusus untuk meramu bahanbahan pewarna alami, seperti kulit mengkudu, kulit buah jalawe, kayu jambal mahoni, kayu jirek, kayu tingi dan lain sebagainya. Proses pewarnaan tidak boleh menggunakan bahan pewarna kimia atau buatan.

Selain yang sudah disebut diatas, batik gentongan memiliki 50 motif khas lainnya yang berkembang di Madura. Motifmotif tersebut menggambarkan karakter demografis, adat istiadat, dan tradisi masyarakat setempat.

Motif-motif tersebut diantaranya adalah, motif Carcena ("cena" adalah dialek Madura untuk menyebut bangsa Cina atau keturunan Tionghoa). Pada motif ini terdapat ornamen-ornamen yang terpengaruh oleh budaya Cina. Motif lainnya adalah motif Sikmelaya, Napaser, Sarpoteh, Sabe, Truci, Panji Sekereng, Panji Tongkol, Panji Suci, Tarpoté kelléngan (tarpoté artinya adalah latar putih, atau batik dengan latar putih), Tarpoté Bangan, Burubur (motif dengan ornamen binatang ubur-ubur), Rewan Méra, Tana Pasér (tanah pasir, motif yang menggunakan banyak isen-isen cecek, atau titik-titik yang menggambarkan tanah berpasir) dan masih banyak yang lainnya.

\section{Penutup}

Batik Madura merupakan salah satu produk kebanggaan masyarakat Madura, tentunya selain karapan sapi dan garamnya. Batik Madura terkenal dengan 
keindahan batiknya yang penuh warna, bernilai seni dan bercita rasa tinggi. Seperti halnya batik dari daerah lain yang memiliki ciri khasnya masing-masing, Madura sebagai salah satu sentra batik di Indonesia menonjolkan ciri khas tersendiri dalam batiknya.

Corak dan ragamnya begitu bebas dan unik. Satu helai kain batiknya dibuat dengan keterampilan individu secara satuan kain. Bahkan saat ini pun mereka masih mempertahankan cara tradisional pembuatannya dengan ditulis menggunakan bahan pewarna alami yang ramah lingkungan.

Batik Madura khususnya dari Tanjung Bumi merupakan pesona batik Nusantara dari Pulau Madura yang telah menjadi salah satu ciri khas Indonesia dan telah menjadi kebiasaan umum untuk digunakan dalam perayaan tertentu ataupun hanya sekedar untuk pakaian sehari-hari. Batik indonesia telah diakui sebagai salah satu pakaian budaya indonesia oleh UNESCO dan ditetapkan tanggal 2 Oktober sebagai hari Batik Nasional.

Batik Tanjung Bumi

Madura merupakan salah satu dari sekian produk batik dari berbagai produsen batik di seluruh negeri yang notabene mempunyai motif tersendiri dalam hal pengemasan batik yang diimplementasikan ke dalam selembar kain untuk selanjutnya di motif sesuai dengan apa yang telah ada sebelumnya. Batik dengan ciri tertentu inilah yang menjadi sumber kekayaan berbagai macam model cara pembuatan batik di Indonesia.

Batik Madura sebagaimana batik pada umumnya membutuhkan kehalusan, keuletan, kesabaran, ketelatenan tingkat tinggi agar tercipta kain batik yang benarbenar berkualitas. Belajar cara membuat batik pun membutuhkan waktu yang tidak sedikit bahkan mungkin membutuhkan waktu sekitar 1 tahun agar benar-benar mengerti bagaimana proses membatik yang benar dengan tidak meninggalkan motif yang telah menjadi turun temurun dikalangan para pembatik. Batik Madura yang terkenal di daerah Tanjung Bumi adalah salah satu pembuat bahkan produsen batik di Madura yang motifnya bagus dan sering dipakai oleh para pejabat ketika menghadiri acara penting sebagai salah satu pakaian santai ataupun resmi.

Batik Madura yang berasal dari Kecamatan Tanjung Bumi Kabupaten Bangkalan ini mempunyai beberapa keunikan dibanding dari daerah lainnya di Indonesia, salah satu motif yang sering digunakan adalah motif burung, kupu-kupu, kapal, perahu, udang, binatang laut lain dan sebagainya yang menggambarkan kondisi dan adat-istiadat masyarakat setempat dan jika ditotal maka keseluruhan motif Batik Tanjung Bumi ini mencapai sekitar 100 Motif.

Sedikit tips yang diperlukan saat berburu batik Madura, untuk membedakan batik tulis dengan batik cap-tulis, yaitu:

1. Batik Cap (untuk sebagian latar seperti memakai batik cap, dan pengrajin menambahkan bunga-bunganya dengan tulis)

- batik cap pasti ada sambungan.

- monoton dan simetris.

- biasanya sudah ada jahitan pada tepian kainnya.

- sulur-sulurnya yang memakan porsi sebagian besar area kain.

2. Batik yang murni tulis

- tidak ada jahitan pada tepi kainnya. 
- coraknya unik atau tidak monoton.

- tidak memiliki motif latar belakang yang rumit.

Batik Madura memiliki jenis motif yang sangat kaya, disamping warnanya yang terang dan cerah, hal ini sesuai dengan karakter masyarakat setempat dan sesuai dengan ciri khas batik pesisir pada umumnya. Dengan kurang dikenalnya batik Madura, dibandingkan dengan batik Pekalongan dan Cirebon serta batik Lasem, diharapkan pengenalan akan batik Madura dalam tulisan ini akan memberikan sedikit gambaran tentang keindahan batik pesisir Madura. Seperti kata pepatah lama: "tak kenal maka tak sayang".

\section{Daftar Pustaka}

Heringa, Rens, Harmen C., Veldhuisen, Batik from the North Coast of Java, Los Angeles County Museum of Art, LA, 2006

HI., William Kwan, Dyah Rosina, Aulia Hadi, Eksplorasi Sejarah Batik Madura, Institut Pluralisme Indonesia, Jakarta, 2010

Ishwara, Helen, Ir. Supriyanto Yahya, Xenia Moeis, Batik Pesisir : An Indonesian Heritage, KPG (Kepustakaan Populer Gramedia), 2012

Ishwara, Helen, Ir. Supriyanto Yahya, Xenia Moeis, Benang Raja : Menyimpul Keelokan Batik Pesisir, KPG (Kepustakaan Populer Gramedia), 2013

Maxwell, Robyn, Textille of Southern Asia : Tradition, Trade and
Transformation, Tuttle Publishing, 2010

Musman, Asti dan Ambar B. Arini, Batik:Warisan Adiluhung Nusantara, G-Media, ANDI Offset, Jakarta, 2011

Kusriyanto, Adi, Batik-Filosofi, Motif dan Kegunaannya, CV. Andi Offset, Yogyakarta, 2013

Lee, Chor Lin, Batik, Creating and Identity, National Museum of Singapore, Stamford Road, SG. 2007

Royen, Van, Batik Design, The Peppin Press BV, Singapore, 2010

Veldhuisen, Harmen C., Batik Belanda 18401940, Dutch Influence in Batik from Java History and Stories, PT Gaya Favorit Press, Jakarta 2003

\section{Webtografi}

arumsekartaji.wordpress.com

http://artscraftindonesia.com/ind/index.p hp?option=com_content $\&$ task=view $\&$ id $=4$ 5

http://www.kriyalea.com/sejarah-batikmadura/.

http://www.tretans.com/2012/09/batikkhas-madura-batik-tanjung-bumi.html.

http://yuliantinote.wordpress.com/2013/0 5/08/batik-madura/

http://zkarnain.tripod.com/SBAYA-13.HTM 